\title{
ANALISIS PENERAPAN \\ CORPORATE SOCIAL RESPONSIBILTY (CSR) DALAM PERSPEKTIF SHARIA ENTERPRISE THEORY
}

\author{
Feri Irawan \\ STAI Nahdlatul wathan Samawa NTB \\ feri.irawan@stainwsamawa.ac.id \\ Eva Muarifah \\ IAIN Syekh Nurjati Cirebon \\ eva.bripda35@gmail.com
}

\begin{abstract}
Abstrak: Corporate Social Responsibility (CSR) merujuk pada semua hubungan yang terjadi antara perusahaan dengan semua stakeholders, termasuk pelanggan, pegawai, komunitas, pemilik, pemerintah, supplier bahkan kompetitor. CSR merupakan konsep di mana Bank Syariah Mandiri (BSM) secara sukarela menyumbangkan sesuatu ke arah masyarakat yang lebih baik dan lingkungan hidup yang lebih bersih. Penelitian ini bertujuan untuk menganalisis Penerapan Corporate Social Responsibility dalam Perspektif Sharia Enterprise Theory (Studi Kasus Pada Bank Syariah Mandiri KC Majalengka). Penelitian ini menggunakan metode studi kasus terhadap Bank Syariah Mandiri dan analisis didasarkan pada item-item pengungkapan tanggung jawab sosial berdasarkan Sharia Enterprise Theory, data primer dan sekunder, teknik pengumpulan data melalui teknik dokumentasi guna


mengambil bukti dilaksanankanya data yang berkaitan dengan Bank Syariah Mandiri KC Majalengka dengan cara pengamatan langsung serta melakukan wawancara terhadap pihak yang bersangkutan (informan). Selanjutnya penulis menganalisa dengan metode analisis deskriptif kualitatif. Penelitian ini dilakukan dengan menganalisis kesesuaian penerapan Corporate Social Responsibility (CSR) di Bank Syariah Mandiri dengan Perspektif Sharia Enterprise Theory. Hasil penelitian ini menunjukkan dalam pelaksanaan Corporate Social Responsibility di Bank Syariah Mandiri bekerja sama dengan Lembaga Amil Zakat Nasional Bangun Sejahtera Mitra Umat (LAZNAS BSM). Yang mana lembaga ini dibangun oleh Yayasan Bangun Sejahtera Mitra Umat (BSM Umat) dan dikukuhkan sebagai Lembaga Amil Zakat Dalam menjalankan kegiatannya, LAZNAS ini memiliki 3 jenis program unggulan, antara lain ;Program Mitra Umat, program Didik Umat dan Program Simpati Umat. Konsep dan Implementasi Sharia Enterprise Theory di Bank Syariah Mandiri KC Majalengka meliputi; Akuntabilitas Vertikal, Akuntabilitas Horizontal (Direct Stakeholders dan Indirect Stakeholders) dan Akuntabilitas Horizontal (Alam). Secara garis besar Corporate Social Responsibility yang dilakukan di Bank Syariah Mandiri KC Majalengka sudah sesuai dengan konsep Shariah Enterprise Theory.

Kata Kunci: Corporate Social Responsibility, Bank Syariah, Sharia Enterprise Theory, Bank Syariah Mandiri.

\section{PENDAHULUAN}

Konsep teoritis mengenai Bank Islam muncul pertama kali pada tahun 1940-an dengan gagasan mengenai perbankan yang berdasarkan bagi hasil. ${ }^{1}$ Corporate Social Responsibility diangkat menjadi isu dunia sebagai tanda keprihatinan terhadap keadaan dunia akhir-akhir ini. Dengan kata lain, bahwa akhir-akhir ini banyak orang berbicara dan menulis tentang CSR karena hanya sedikit tanggung jawab sosial yang dilakukan oleh perusahaan bila dibandingkan beberapa dekade yang lalu. Maksud CSR dalam penelitian ini adalah tanggung jawab sosial perusahaan PT.Bank Syariah Mandiri, Program CSR Bank Mandiri tersebut memberikan bantuan berupa dana untuk membantu masyarakat memandirikan

\footnotetext{
${ }^{1}$ Ismail, Perbankan Syariah,(Jakarta: Kencana Prenada Media Grup, 2011). 29-30.
} 
mereka sendiri melalui pengembangan Skill, Fasilitas dan pengembangan pertanian.

Corporate Social Responsibility (CSR) berarti tanggung jawab sosial perusahaan terhadap masyarakat. Perusahaan melalui program-program CSR nya melakukan kegiatan untuk memelihara lingkungan khususnya di lingkungan sekeliling perusahaan serta perusahaan juga membantu meningkatkan kesejahteraan masyarakat. Penerapan CSR merupakan praktik yang dibentuk berdasarkan nilai-nilai norma yang berlaku di masyarakat. Pada sektor perbankan syariah, nilai-nilai norma yang digunakan adalah nilai-nilai agama Islam, atau disebut juga dengan nilainilai syariah. Perusahaan sebagai sebuah entitas badan hukum memiliki tanggung jawab sosial perusahaan (Corporate Social Responsibility/CSR).

Dalam praktiknya selama ini masih terdapat beberapa perusahaan yang melaksanakan program tanggung jawab sosial perusahaan/CSR hanya bersifat sukarela (voluntary). dari keseluruhan perusahaan yang beroperasi di Indonesia, dan kegiatannya sendiri lebih terfokus pada kedermawanan (philanthropy) dan kemurahan hati (charity) dalam rangka membantu korban bencana alam. Padahal kegiatan tanggung jawab sosial perusahaan/CSR merupakan suatu komitmen bersama yang berkelanjutan dari seluruh stakeholders perusahaan untuk bersama-sama bertanggung jawab terhadap masalah-masalah sosial. ${ }^{2}$

Tanggung jawab sosial perusahaan/ CSR lebih menunjukkan kepedulian perusahaan terhadap kepentingan pihak-pihak secara lebih luas (stakeholders) daripada hanya sekedar mementingkan kepentingan perusahaan sendiri. Tanggung jawab sosial perusahaan/ CSR berkaitan dengan hubungan antara perusahaan dengan pelanggan, karyawan, pemasok, investor, komunitas masyarakat, pemerintah, dan juga kompetitornya.

Kepedulian perusahaan sebagai bagian dari tanggung jawab sosial perusahaan/ CSR terwujud dalam komitmen perusahaan untuk mempertanggungjawabkan dampak-dampak dari kegiatan usaha yang dijalankannya dalam aspek ekonomi, sosial, dan lingkungan yang sejalan dengan konsep Triple Bottom Line. Tanggung jawab sosial perusahaan/CSR juga bertujuan sebagai bentuk tanggung jawab perusahaan untuk mengatasi dampak dari keputusan-keputusan dan kegiatan-kegiatan perusahaan.Tidak dapat dipungkiri selain dampak positif yang timbul dari berdirinya sebuah perusahaan, terdapat pula

\footnotetext{
2 Akmal Lageranna, Pelaksanaan tanggung jawab sosial perusabaan (CSR) pada perusabaan Industri rokok; studi pada PT Djarum Kudus, Jawa STengah, Universitas Hasanudin Makassar, 2013.
} 
dampak negatif yang ditimbulkan dari usaha kegiatan yang dijalankan sebuah perusahaan.

Perusahaan yang berbasis sumber daya alam dalam menjalankan kegiatan industrinya secara tidak langsung memberikan dampak pada fungsi kemampuan sumber daya alam.Kewajiban pelaksanaan tanggung jawab sosial perusahaan/ CSR yang telah menjadi tanggung jawab hukum perusahaaan dari segi ekonomis dianggap tidak menguntungkan, tetapi jika dilakukan dengan benar,efektif, terstruktur, dan bersifat jangka panjang bukan hal yang mustahil jika kegiatan tersebut dapat memberi keuntungan ekonomis kepada perusahaan.

Termasuk dalam hal ini salah satu jenis perusahaan/ lembaga keuangan yang memiliki tanggung jawab sosial perusahaan/CSR adalah perusahaan/ lembaga keuangan Bank Syariah Mandiri. Kehadiran BSM sejak tahun 1999, sesungguhnya merupakan hikmah sekaligus berkah pasca krisis ekonomi dan moneter 1997-1998. ${ }^{3}$ Sebagaimana diketahui, krisis ekonomi dan moneter sejak Juli 1997, yang disusul dengan krisis multi-dimensi termasuk di panggung politik nasional, telah menimbulkan beragam dampak negatif yang sangat hebat terhadap seluruh sendi kehidupan masyarakat, tidak terkecuali dunia usaha. Dalam kondisi tersebut, industri perbankan nasional yang didominasi oleh bank-bank konvensional mengalami krisis luar biasa. Pemerintah akhirnya mengambil tindakan dengan merestrukturisasi dan merekapitalisasi sebagian bank-bank di Indonesia. Corporate Social Responsibility (CSR) merujuk pada semua hubungan yang terjadi antara perusahaan dengan semua stakeholders, termasuk pelanggan, pegawai, komunitas, pemilik, pemerintah, supplier bahkan kompetitor.

Corporate Social Responsibility merupakan konsep di mana Bank Syariah Mandiri secara sukarela menyumbangkan sesuatu ke arah masyarakat yang lebih baik dan lingkungan hidup yang lebih bersih. Kegiatan-kegiatan yang dijalankan BSM di tahun 2009 terus diupayakan agar sesuai dengan konsep dasar CSR, yaitu membantu mengatasi atau mengurangi permasalahan yang terjadi di masyarakat, mengusahakan terjadinya perubahan perilaku masyarakat, dan mengupayakan pencapaian kesejahteraan kehidupan masyarakat. ${ }^{4}$ Kegiatan Corporate Social Responsibility (CSR) diatur dalam UU No. 40 tahun 2007 tentang perseroan terbatas. Dari UU tersebut pemerintah Indonesia mewajibkan

3 Diakses dari https://www.syariahmandiri.co.id/category/info-perusahaan/profilperusahaan/sejarah/pada tanggal 15 mei 2017 pukul 20.00 WIB.

${ }^{4}$ Diakses dari https://www.syariahmandiri.co.id/category/csr/ pada tanggal 15 mei 2017 pukul 20.00 WIB. 
setiap perusahaan untuk melakukan tanggung jawab sosial kepada masyarakat Indonesia.

Saat ini kriteria penilaian kinerja perbankan syariah hanya mengacu pada laba perusahaan yang disajikan dalam laporan keuangan konvensional, dimana didasarkan pada proprietary theory dan entity theory yang mana hanya terfokus pada laba. Jika proprietary theory dan entity theory dianggap kurang sesuai dengan tujuan yang dimiliki oleh bisnis Islam, maka yang dianggap mewakili adalah enterprise theory karena dalam teori ini perusahaan tidak hanya berfokus pada laba tapi juga pada pada stakeholder, namun enterprise theory dianggap belum dapat menampung aspek pertanggungjawaban dan ketundukan terhadap syariah.

Maka sharia enterprise theory yang dianggap lebih dapat mewakili bagaimana kinerja entitas bisnis Islam diukur dan dilaporkan karena memiliki cakupan akuntabilitas yang lebih luas dibandingkan dengan Enterprise Theory (ET) dan dikembangkan berdasarkan metafora zakat yang pada dasarnya memiliki karakter keseimbangan. Tujuan dari penelitian ini adalah mengetahui bagaimana pertanggungjawaban perbankan syariah kepada stakeholders apabila menggunakan shariah enterprise theory melalui value added statement.

Bank Syariah Mandiri adalah bagian dari BUMN, maka Bank Syariah Mandiri juga mempunyai Corporate Social Responsibility, salah satu program CSR dari Bank Syariah Mandiri adalah Mandiri Bersama Mandiri (MBM). Arti dari program MBM tersebut adalah sebagai bentuk kepedulian Bank Syariah Mandiri terhadap pertumbuhan jumlah wirausaha untuk menunjang perekonomian di Indonesia. Bentuk Program MBM berupa pengembangan pertanian dan pengembangan potensi yang ada dalam Desa.

\section{PEMBAHASAN}

Konsep dasar Bank syariah didasarkan pada Al-Qur'an dan Hadis. Semua produk dan jasa yang ditawarkan tidak boleh bertentangan dengan isi Al-Qur'an dan hadis Rasulullah SAW.Bank merupakan lembaga keuangan yang aman dalam melakukan berbagai macam aktivitas keuangan. Aktivitas keuangan yang sering dilakukan masyarakat di negara maju dan negara berkembang antara lain aktivitas penyimpanan dan penyaluran dana Menurut Undang-undang Perbankan Nomor 10 Tahun 1998 yang dimaksud dengan bank adalah badan usaha yang menghimpun dana dari masyarakat dalam bentuk simpanan dan

\footnotetext{
5 Muhammad. Manajemen Bank Syariah. (Yogyakarta: Penerbit Unit penerbit dan percetakan Sekolah Tinggi Ilmu Manajemen YKPN, 2011):15
} 
menyalurkan ke masyarakat dalam bentuk kredit dan/atau bentuk lainnya dalam rangka meningkatkan taraf hidup rakyat banyak.

Bank menghimpun dana masyarakat kemudian menyalurkan dananya kepada masyarakat dengan tujuan untuk mendorong peningkatan taraf hidup rakyat banyak. Dua fungsi pokok bank yaitu penghimpunan dana masyarakat dan penyaluran dana kepada masyarakat, oleh karena itu disebut Financial Intermediary. Bank yang beroperasi sesuai dengan prinsip-prinsip syariah Islam maksudnya adalah bank yang dalam beroperasinya itu mengikuti ketentuan-ketentuan syariah Islam, khususnya yang menyangkut tata cara bermuamalah secara Islam. Dalam tata cara bermuamalat itu dijauhi praktik-praktik yang dikhawatirkan mengandung unsur-unsur riba, untuk diisi dengan kegiatan-kegiatan investasi atas dasar bagi hasil dan pembiayaan perdagangan atau praktikpraktik usaha yang dilakukan di zaman Rasulullah atau bentuk-bentuk usaha yang telah ada sebelumnya, tetapi tidak dilarang oleh beliau.

\section{Definisi Bank Menurut Para Ahli}

Sedangkan menurut Sutan Remy Shahdeiny Bank Syariah adalah lembaga yang berfungsi sebagai intermediasi yaitu mengerahkan dana dari masyarakat dan menyalurkan kembali dana-dana tersebut kepada masyarakat yang membutuhkan dalam bentuk pembiayaan tanpa berdasarkan prinsip bunga, melainkan berdasarkan prinsip syariah. Menurut undang-undang No. 21 tahun 2008, bank syariah adalah bank yang menjalankan kegiatan usahanya berdasarkan prinsip syariah dan menurut jenisnya terdiri atas Bank Umum Syariah dan Bank Pembiayaan Rakyat Syariah.

Pengertian bank didalam bukunya "Dictionary of Banking and Finance mengenai pengertian bank adalah "Bank is an organization atau bank adalah suatu badan atau organisasi, biasanya dalam bentuk perusahaan dan bekerjasama atau disewa dengan pemerintah, untuk melakukan penerimaan deposito dan giro yang berjangka, membayar bunga yang ada pada mereka sebagaimana yang telah diizinkan oleh hukum yan gberlaku, membuat catatan diskon, memberikan sebuah pinjaman, berinvestasi didalam pemerintahan atau pada surat berharga lainnya.

Pengertian Bank menurut Dr. B.N. Ajuha menyatakan bahwa pengertian Bank adalah suatu tempat untuk menyalurkan modal dari mereka yang tidak mampu menggunakan secara mengunntungkan kepada mereka yang dapat membuatnya lebih produktif untuk keunntungan masyarkaat. Pengertian bank menurut Pierson menyatakan bahwa Bank adalah suatu badan usaha yang menerima kredit tetapi tidak memberrikan kredit. Dalam hal ini menurut Pierson bahwa bank dalam 
menjalankan tugasnya hanya bersifat passif saja, hanya sekedar menerima titipan uang.

Pengertian bank menurut Drs. H. Malayu S.P. Hasibuan menjelaskan bahwa Bank adalah suatu badan usaha yang kekayaannya dalam bentuk aset keuangan serta bermotiffkan profit dan jugga sosial, jadi tidak hanya untuk mencari keuntungan saja. Jadi, penulis berkesimpulan bahwa bank syariah adalah bank yang operasionalnya menghimpun dana dari masyarakat dan menyalurkan kepada masyarakat berupa pembiayaan dengan sistem bagi hasil yang berdasarkan ketentuan- ketentuan syariat islam.

\section{Dasar Hukum Bank Syariah}

Didalam mengoperasionalkan bank syariah, dasar hukum pertama adalah Al-Qur'an dan Hadits. Beberapa ayat di dalam Al-Qur'an sebagai dasar operasional bank syariah, antara lain :

Ar Ruum Ayat 39

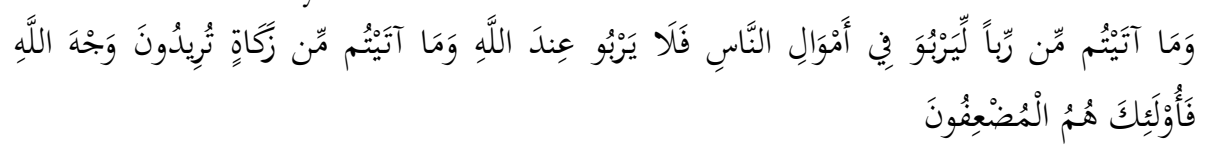

Dan sesuatu riba (tambahan) yang kamu berikan agar dia bertambah pada harta manusia, maka riba itu tidak menambah pada sisi Allah. Dan apa yang kamu berikan berupa zakat yang kamu maksudkan untuk mencapai keridhaan Allah, maka (yang berbuat demikian) itulah orang-orang yang melipat gandakan (pahalanya). ${ }^{6}$

Barang siapa yang memberikan sesuatu kepada seseorang dengan harapan orang itu akan membalas dengan pemberian yang lebih banyak daripada yang telah diberikannya, maka pemberian yang demikian tidak berpahala di sisi Allah. Sedangkan orang yang memberikan zakat kepada seseorang dengan tujuan untuk mendapatkan keridhaan Allah, maka akan dilipatgandakan pahala dan balasan si pemberinya oleh Allah.

Tafsir Al Baqarah Ayat 279

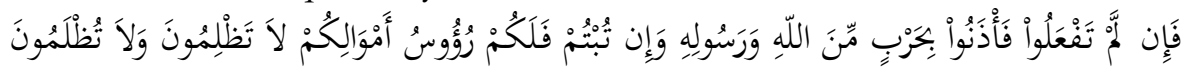

Maka jika kamu tidak mengerjakan (meninggalkan sisa riba), maka ketahuilah, bahwa Allah dan Rasul-Nya akan memerangimu. Dan jika kamu bertaubat (dari pengambilan riba), maka bagimu pokok. bartamu; kamu tidak menganiaya dan tidak (pula) dianiaya.

\footnotetext{
${ }^{6}$ Adiwarman A Karim, Bank Syariah analisis Fiqih dan Kenangan- edisi keempat ( Jakarta: PT Rajagrafindo persada ,2004), 41
} 
Ayat ini masih berhubungan dengan ayat pada post sebelumnya sebagai penjelas atas akibat apabila tidak ditinggalkannya riba.

Perkembangan perbankan syariah belum diimbangi dengan kemajuan di bidang hukum perbankan syariah, dengan tidak adanya undang-undang (UU) yang secara spesifik mengelaborasi kekhusussan perbankan sayariah. Jika dihitung rentan waktu antara pendirian perbankan syariah (Tahun 1980)dengan pembentukan UU No.21 tahun 2008 tentang perbankan syariah.

\section{Perbankan Syariah Dalam UU}

Sebelum UU Perbankan Syariah disahkan, posisi perbankan syariah di Indonesia cukup mengambang, kaarena didukung oleh konstitusi, namun tidak diatur dalam peraturan perundang-undangan yang berada di bawahnya. Memang di Indonesia sudah ada UU No.7 Tahun 1992 tentang perbankan sebagai mana telah diubah dengan UU No. 10 Tahun 1998. Namun dalam UU ini ketentuan tentang perbankan syariah sangat minim sehingga tidak bisa menjadi jawaban terhadap keunikan dan kekhususan perbankan syariah. ${ }^{7}$

Dalam pasal 1 angka 13 UU NO.10 Tahun 1998 prinsip syariah di jelaskan sebagai prinsip aturanperjanjian berdasarkan hukum islam seperti pembiayaan berdasarkan prinsip bagi hasil (mudharabah), pembiayaan berdasarkan prinsip penyertaan modal (musyarakah),prinsip jual beli barang dengan memperoleh keuntungan (murabahah), atau pembiayaan barang modal berdasarkan prinsip sewa murni tanpa pilihan (ijarab), atau dengan adanya pilihan pemindahan kepemilikan atas barang yang di sewa dari pihak bank dan oleh pihak lain (ijarah wa iqtina).

Sebagai UU yang khusus mengatur perbankan syariah, dalam UU ini diatur mengenai masalah keputusan syariah(syariah compliance) yang kewenangannya berada pada majlis ulama Indonesia (MUI) yang direpresenctasikan melalui dewan pengawas syariah (DPS) yang harus dibentuk pada masing-masing bank syariah dan UUS. Untuk menindak lanjuti implementasi fatwa yang dikeluarkan MUI kedalam PBI, di dalam internal bank Indonesia di bentuk komite perbankan syariah, yang keanggotaannya terdiri atas perwakilan bank Indonesia, departemen agama, dan unsure masyarakat yang komposisinya berimbang.

\section{Perbankan Syariah Dalam Peraturan Bank Indonesia}

\footnotetext{
Adiwarman A Karim, Bank Syariah analisis Fiqih dan Kenangan- edisi keempat ( Jakarta : Pt Rajagrafindo persada ,2004), 58
} 
Peraturan bank Indonesia (PBI) adalah peraturan yang dikeluarkan oleh bank Indonesia untuk mengawasi dan membina semua bank yang berbadan hukum Indonesia atau beroperasi di Indonesia. PBI yang lahir sebelum 1 November 2004 tetap mempunyai kekuatan hukum. Seperti dalam pasal 7 ayat (4) UU No. 10 Tahun 2004 yang menegaskan bahwa peraturan yang dikeluarkan lembaga Negara lain, seperti Bank Indonesia, yang bersifat mengatur mempunyai kekuatan hukum selama diperintahkan oleh perundang-undangan, yang dalam hal ini oleh UUD, UU, Perpu, PP, dan perpres.

Dengan begitu PBI tidak boleh berdiri sendiri, melainkan harus merujuk atau melaksanakan perintah salah satu hierarki hukum di atas. PBI yang lahir setelah 1 november 2004 harus menyesuaikan dengan ketentuan dalam UU No. 10 tahun 2004. Karena PBI tidak termasuk dalam hierarki hukum nasional. Oleh karena itu, proses kelahirannya, PBI harus ada perintah dari peraturan perundang-undanganyang disebutkan dalam pasal 7, yaitu UUD, perpu, UU, PP, dan Perpres (pasal 7 ayat 4 UU No. 10 Tahun 2004) Pengesahan UU Perbankan Syariah memberikan kekuatan atas keberadaan PBI dalam mengatur perbankan syariah, karena diperintahkan oleh UU yang secara khusus mengatur perbankan syariah.

Dalam UU Perbankan Syariah banyak pasal-pasal yang memerintahkan "ketentuan lebih lanjut mengenai hal tertentu diatur dalam PBI." Terdapat 21 ketentuan dalam UU Perbankan Syariah yang memerintahkan pengaturan lebih lanjut hal tertentu dalam PBI. ${ }^{8}$

\section{Prinsip-prinsip Bank Syariah}

Prinsip dasar perbankan syariah berdasarkan pada al-Quran dan sunnah. Setelah dikaji lebih dalam Falsafah dasar beroperasinya bank syariah yang menjiwai seluruh hubungan transaksinya berprinsip pada tiga hal yaitu efisiensi, keadilan, dan kebersamaan. Efisiensi mengacu pada prinsip saling membantu secara sinergis untuk memperoleh keuntungan/margin sebesar mungkin. Keadilan mengacu pada hubungan yang tidak dicurangi, ikhlas, dengan persetujuan yang matang atas proporsi masukan dan keluarannya. Kebersamaan mengacu pada prinsip saling menawarkan bantuan dan nasihat untuk saling meningkatkan produktivitas.

Dalam mewujudkan arah kebijakan suatu perbankan yang sehat, kuat dan efisien, sejauh ini telah didukung oleh enam pilar dalam Arsitektur Perbankan Indonesia (API) yaitu, struktur perbankan yang

\footnotetext{
8 Adiwarman A Karim, Bank Syariah analisis Fiqih dan Keuangan-edisi keempat ( Jakarta: Pt Rajagrafindo persada ,2004), 74
} 
sehat, sistem pengaturan yang efektif, system pengawasan yang independendan efektif, industri perbankan yang kuat, infrastruktur pendukung yang mencukupi, dan perlindungan konsumen. ${ }^{9}$

Daya tahan perbankan syariah dari waktu ke waktu tidak pernah mengalami negative spread seperti bank konvensional pada masa krisis moneter dan konsistensi dalam menjalankan fungsi intermediasi karena keunggulan penerapan prinsip dasar kegiatan operasional yang melarang bunga (riba), tidak transparan (gharar), dan (maisir) spekulatif.

\section{Definisi secara umum Corporate Social Responsibility (CSR)}

Salah satu faktor keberhasilan suatu perusahaan adalah dimana perusahaan yang melakukan aktifitas kegiatan tanggung jawab sosial. Corporate Social Responsibility merupakan gagasan yang menjadikan perusahaan tidak lagi di hadapkan pada tanggung jawab yang berpijak pada nilai perusahaan tetapi pada tanggung jawab sosial yang harus berpijak pada triple bottom line yang harus memperhatikan masalah sosial dan lingkungan. Ada berbagai definisi tentang CSR, antara lain definisi CSR menurut The World Business Council For Sustainable Development (WBCSD) sebagai berikut: ${ }^{10}$

"Continuing commitment by business to behave ethically and contribute to economic development while improving the quality of life of the work-force and their families as well as of the local community and society at large".

Eirbert mendefinisikan corporate social responsibility sebagai: "Usaha perusahaan untuk menyeimbangkan komitmen-komitmennya terhadap kelompok-kelompok dan individual-individual dalam lingkungan perusahaan tersebut, termasuk di dalamnya adalah pelanggan, perusahaan-perusahaan lain, para karyawan, dan investor." CSR berusaha memberikan perhatian terhadap lingkungan dan sosial ke dalam operasionalnya.

Sebagaimana dijelaskan oleh Darwin: "Tanggung jawab sosial adalah mekanisme bagi suatu organisasi untuk secara sukarela mengintegrasikan perhatian terhadap lingkungan dan sosial ke dalam organisasinya dan interaksinya dengan pihak-pihak yang berkepentingan, yang melebihi tanggungjawabnya dibidang hukum."

\section{Definisi Menurut Para Ahli}

\footnotetext{
${ }_{9}^{9}$ Muhammad, Manajemen Bank Syariah, ( Yogyakarta : Sekolah Tinggi Ilmu Manajemen YKPN, 2011), 45

${ }_{10}$ Rivandiyanto Suhirman, Pengarub CSR Struktur modal dan grup Corporate governance terhapad kinerja keuangan (Unswagati, 2016)
} 
Definisi tentang Corporate Social Responsinbility sangat beragam, selain ada definisi CSR secara global maka ada juga beberapa definisi menurut para ahli atau lembaga bisnis. Berikut adalah beberapa definisi tentang Corporate Social Responsibility : ${ }^{11}$ Menurut Nuryana (2005) disitir oleh Fahmi (2014:81): "Corporate Social responsibility adalah komitmen perusahaan atau dunia bisnis untuk berkontribusi dalam pengembangan ekonomi yang berkelanjutan dengan memperhatikan tanggung jawab sosial perusahaan dan menitik beratkan pada keseimbangan antara perhatianterhadap aspek ekonomis, sosial dan lingkungan.

Secara konseptual, CSR adalah sebuah pendekatan dimana perusahaan mengintegrasikan kepedulian sosial dalam operasi bisnis mereka dan dalam interaksi mereka dengan para pemangku kepentingan (stakeholder) berdasarkan prinsip kesukarelaan dan kemitraan."

Menurut K Clement Sankat disitir oleh Rudito (2002) :“Corporate Social responsibility adalah komitmen usaha untuk bertindak secara etis, beroperasi secara legal dan berkontribusi untuk meningkatkan ekonomi bersamaan dengan peningkatan kualitas hidup dari karyawan dan keluarganya, komunitas lokal dan masyarakat secara lebih luas."

CSR menurut pendapat The World Business Council For Sustainable Development (WBCSD) (fox et al, 2002 dalam Lindrawati, Felicia dan Budianto, 2008 ) mendefinisikan bahwa: "Corporate Sosial Responsibility adalah komitmen bisnis untuk berkontribusi dalam pembangunan ekonomi berkelanjutan, bekerja dengan para karyawan perusahaan, keluarga karyawan tersebut, beserta komunitas-komunitas setempat dan masyarakat secara keseluruhan, dalam rangka meningkatkan kualitas kehidupan"Hal yang senada menurut pendapat Rusdianto (2013:7) menyatakan bahwa: "CSR mengandung arti bahwa organisasi bukan lagi sebagai entitas yang hanya mementingkan dirinya sendiri (selfish). Sehingga teralienasi dari lingkungan masyarakat ditempat mereka bekerja, melainkan sebuah entitas usaha yang wajib melakukan adaptasi kultural dengan lingkungan sosialnya. Konsep ini menyediakan jalan bagi setiap perusahaan untuk melibatkan dirinya dengan dimensi sosial dan memberikan perhatian terhadap dampak-dampak sosial yang ada"

Menurut Rawi dan Muchlid (2010) menyatakan bahwa :

"Corporate Social Responsibility adalah mekanisme bagi suatu organisasi untuk secara sukarela mengintegrasikan perhatian terhadap lingkungan dan sosial kedalam operasinya dan interaksinya dalam steakeholders, yang melebihi tanggung jawab organisasi di bidang hukum."Sedangkan Sudarto dalam Listiyanti (2011) mendefinisikan bahwa: "Tanggung jawab sosial dan lingkungan perusahaan adalah bentuk kepedulian perusahaan

11 Ibid. 
untuk menyisihkan sebagian keuntungannya (profit) bagi kepentingan pembangunan manusia (people) dan lingkungan (planet) secara berkelanjutan berdasarkan prosedure (procedure) yang tepat dan profesional." 12

Dari beberapa pendapat para ahli tentang pengertian Corporate Social Responsibility, maka dapat disimpulkan bahwa CSR adalah kewajiban perusahaan untuk menggunakan sumber dananya dengan cara untuk memberi manfaat kepada masyarakat, melalui partisipasi sebagai anggota masyarakat, mempertimbangkan aspek kemasyarakatan secara lebih luas dan memperbaiki kesejahteraan masyarakat luas, terlepas manfaat langsung yang diterima perusahaan.

\section{Peran Tanggung Jawab Sosial dan lingkungan (CSR)}

Khusus untuk berbentuk Perseroan Terbatas (PT) ada yang disebut dengan Tanggung Jawab Sosial dan Lingkungan. Tanggung Jawab Sosial dan Lingkungan adalah komitmen Perseroan untuk berperan serta dalam pembangunan ekonomi berkelanjutan guna meningkatkan kualitas kehidupan dan lingkungan yang bermanfaat, baik bagi Perseroan sendiri, komunitas setempat, maupun masyarakat pada umumnya. Tentanf tanggungjawab sosial dan lingkungan diatur secara spesifik dalam pasal 74 UU Nomor 40 Tahun 2007 :

1. Peseroan yang menjalankan kegiatan usahanya dibidang dan/atau berkaitan dengan sumber daya alam wajib melaksanakan Tanggung Jawab Sosial dan Lingkungan.

2. Tanggung Jawab Sosial dan lingkungan sebagaimana dimaksud pada ayat (1) merupakan kewajiban Perseroan yang dianggarkan dan diperhitungkan sebagai biaya Perseroan yang pelaksanaannya dilakukan dengan memperhatikan kepatutan dan kewajiban.

3. Perseroan yang ridak melaksanakan kewajiban sebagaimana dimaksud pada ayat (1) dikenI sanksi sesuai dengan ketentuan peraturan perundang-undangan.

4. Ketentuan lebih lanjut mengenai Tanggung Jawab Sosial dan Lingkungan diatur dengan Peraturan Pemerintah. ${ }^{13}$

\section{CSR dalam Perspektif Islam}

Perbuatan tanggung jawab begitu mendasar dalam ajaran-ajaran Islam. Manusia memang memiliki kebebasan dalam berbuat tetapi, juga

\footnotetext{
12 Rivandiyanto Suhirman, Pengarub CSR Struktur modal dan grup Corporate governance terhapad kinerja kenangan ( Unswagati, 2016 )

${ }^{13}$ Kurniawati,Pengarub Ukuran Dewan Komisaris Dan Tipe Industri terhadap pengungkapan CS (Unswagati : 2016)
} 
memiliki tanggung jawab terhadap lingkungan alam, sosial dan kepada Allah SWT. Jadi, manusia adalah mahluk yang harus memiliki sifat tanggung jawab karena ia memiliki kemampuan untuk memilih secara sadar dalam meraih yang dikehendaki.

Dalam perspektif Islam, CSR merupakan realisasi dari konsep ajaran ihsan sebagai puncak dari ajaran etika yang sangat mulia. Ihsan merupakan melaksanakan perbuatan baik yang dapat memberikan kemanfaatan kepada orang lain demi mendapatkan ridho Allah SW'T. Disamping itu, CSR merupakan implikasi dari ajaran kepemilikan dalam Islam, Allah adalah pemilik mutlaq (baqiqiyah) sedangkan manusia hanya sebatas pemilik sementara (temporer) yang berfungsi sebagai penerima amanah Maka dengan mengemban amanah, individu maupun kelompok harus dapat menjadi khalifah yang dapat berbuat keadilan, bertanggung jawab dan melakukan perbuatan yang bermanfaat.

CSR ternyata selaras dengan pandangan Islam tentang manusia dalam hubungan dengan dirinya sendiri dan lingkungan sosialnya, dapat dipresentasikan dengan empat aksioma yaitu kesatuan (tauhid), keseimbangan (equilibrium), kehendak bebas (free will) dan tanggung jawab (responsibility).Menurut Muhammad Djakfar, Implementasi CSR dalam Islam secara rinci harus memenuhi beberapa unsur yang menjadikannya ruh sehingga dapat membedakan CSR dalam perspektif Islam dengan CSR secara universal yaitu:

Al-adl

Islam telah mengharamkan setiap hubungan bisnis atau usaha yang mengandung kezaliman dan mewajibkan terpenuhinya keadilan yang teraplikasikan dalam hubungan usaha dan kontrak- kontrak serta perjanjian bisnis.

Sifat keseimbangan atau keadilan dalam bisnis adalah ketika korporat mampu menempatkan segala sesuatu pada tempatnya. Dalam beraktifitas di dunia bisnis, Islam mengharuskan berbuat adil yang diarahkan kepada hak orang lain, hak lingkungan sosial, hak alam semesta. Jadi, keseimbangan alam dan keseimbangan sosial harus tetap terjaga bersamaan dengan operasional usaha bisnis, dalam al-Qur'an surat Huud ayat 85 telah menegaskan sebagai berikut:

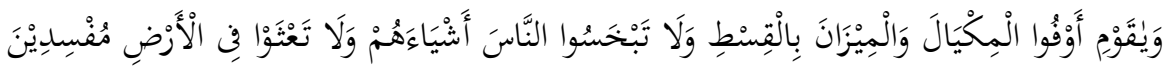

Dan wahai kaumku! Penubilah takaran dan timbangan dengan adil, dan janganlah kamu merugikan manusia terbadap hak-bak mereka dan jangan kamu membuat kejahatan di bumi dengan berbuatkerusakan. 


\section{Sharia Enterprise Theory}

Meskipun enterprise theory oleh beberapa penulis dianggap sebagai teori yang paling pas untuk Akuntansi Syariah karena enterprise theory mengandung nilai keadilan, kebenaran, kejujuran, amanah, dan pertanggungjawaban. Nilai-nilai tersebut telah sesuai dengan karakteristik dari Akuntansi Syariah yang telah dirumuskan oleh Triyuwono, yaitu : humanis, emansipatoris, transedental, dan teleologikal. Namun demikian, enterprise theory masih dibayangi oleh agency theory dan politisasi akuntansi. Enterprise theory masih bersifat "duniawi" dan tidak memiliki konsep tauhid. Agar konsep teoritis ini benar-benar sesuai dengan syariah, maka perlu diinternalisasikan nilai tauhid.

Karena dengan konsep dan nilai tauhid kita dapat memperoleh dapat memperoleh legitimasi untuk memasukkan konsep kepemilikan dalam Islam, konsep zakat, konsep keadilan ilahi, dan konsep pertanggungjawaban.

Dalam sharia enterprise theory menurut Slamet menjelaskan bahwa aksioma terpenting yang harus mendasari dalam setiap penetapan konsepnya adalah Allah sebagai Pencipta dan Pemilik Tunggal dari seluruh sumber daya yang ada di dunia ini. Maka yang berlaku dalam sharia enterprise theory adalah Allah SWT sebagai sumber utama, karena Dia adalah Pemilik Tunggal dan Mutlak dari seluruh sumber daya yang ada di dunia ini. Sedangkan sumber daya yang dimiliki oleh para stakeholders pada prinsipnya adalah amanah dari Allah yang didalamnya melekat sebuah tanggung jawab untuk menggunakan dengan cara dan tujuan yang ditetapkan oleh Sang Pemberi Amanah. Di Surah Al-Baqarah telah dijelaskan hal tersebut. ${ }^{14}$

Surah / surat: Al-Baqarah Ayat : 254

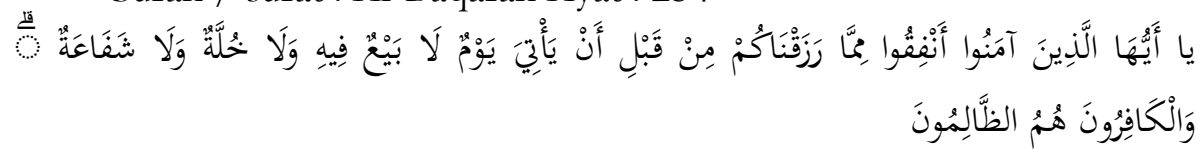

Hai orang-orang yang beriman, belanjakanlah (di jalan Allab) sebagian dari rezki yang telah Kami berikan kepadamu sebelum datang hari yang pada hari itu tidak ada lagi jual beli dan tidak ada lagi syafa' at. Dan orang-orang kafir itulah orang-orang yang zalim.

Tentu sangat beralasan jika penggunaan sumber daya tersebut baik secara individual dan kolektif dibatasi, karena pada hakikatnya stakeholders hanya memiliki hak guna. Namun pembatasan tersebut bukan ditujukan

\footnotetext{
${ }^{14}$ Andri Safitri Hafida "Implikasi Shariah Enterprise Theory melalui value Added Statement untuk menilai tanggung jawab perbankan syariah kepada stakeholder (Unswagati: 2016)
} 
untuk kepentingan Allah, tetapi ditujukan pada manusia yang mempunyai hak atas sumber daya tersebut. Allah berfirman:

Surah/surat: An-Nuur Ayat: 56

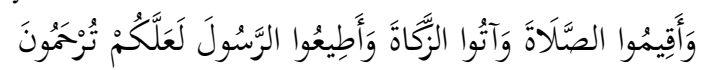

"Dan dirikanlah sembahyang, tunaikanlah zakat, dan ta'atlab kepada rasul, supaya kamu diberi rabmat."

Surah / surat: Al-Baqarah Ayat: 215

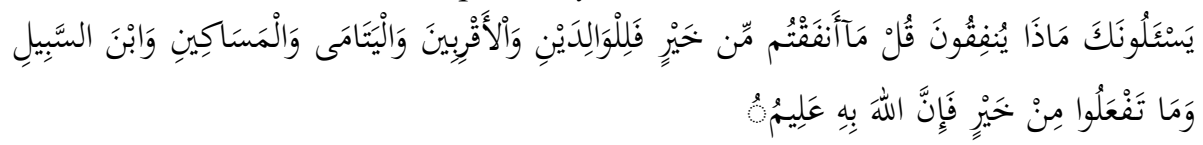

"Mereka bertanya tentang apa yang mereka nafkabkan. Jawablab:

"Apa saja harta yang kamu nafkabkan hendaklab diberikean kepada ibu-bapak, kaum kerabat, anak-anak yatim, orang-orang miskin dan orang-orang yang sedang dalam perjalanan." Dan apa saja kebaikan yang kamu buat, maka sesungguhnya Allah Maha Mengetabuinya."

Ayat-ayat tersebut membawa implikasi penting dalam penetapan konsep-konsep dalam sharia enterprise theory. Yang utama adalah bahwa ayat-ayat tersebut membimbing kita pada suatu pemahaman bahwa dalam harta kita sebenarnya tersimpan hak orang lain, seperti : hak para fakir miskin, anak-anak terlantar, Ibnu Sabil, dan lain-lainnya seperti terlihat pada ayat berikut ini :

Surah / surat: At-Taubah Ayat: 60

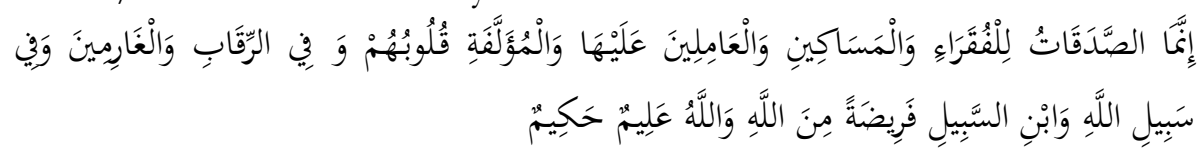

"Sesungguhnya zakat-zakat itu, hanyalah untuk orang-orang fakir, orang-orang miskin, pengurus-pengurus zakat, para mu'allaf yang dibujuk hatinya, untuk (memerdekakan) budak, orang-orang yang berbutang, untuk jalan Allah dan untuk. mereka yuang sedang dalam perjalanan, sebagai suatu ketetapan yang diwajibkan Allah, dan Allah Maba Mengetahui lagi Maha Bijaksana."

Dengan demikian, dalam pandangan shariah enterprise theory, distribusi kekayaan (wealth) atau nilai tambah (value added) tidak hanya berlaku pada para partisipan yang terkait langsung dalam, atau partisan yang memberikan kontribusi kepada, operasi perusahaan; seperti pemegang saham, kreditor, karyawan, dan pemerintah, tetapi pihak lain yang tidak terkait langsung dengan bisnis yang dilakukan perusahaan, atau pihak yang tidak memberikan kontribusi keuangan dan skill. Artinya, cakupan akuntansi dalam sharia enterprise theory tidak terbatas pada 
peristiwa atau kejadian yang bersifat reciprocal antara pihak-pihak yang terkait langsung dalam proses penciptaan nilai tambah, tetapi juga pihak lain yang tidak terkait langsung. Pemahaman ini tentu membawa perubahan penting dalam terminologi enterprise theory yang meletakkan premisnya untuk mendistribusikan kekayaan (wealth) berdasarkan kontribusi para partisipan, yaitu partisipan yang memberikan kontribusi atau keterampilan (skill).

Pada prinsipnya sharia enterprise theory memberikan bentuk pertanggungjawaban utamanya kepada Allah (vertikal) yang kemudian dijabarkan lagi pada bentuk pertanggungjawaban (horizontal) pada umat manusia dan lingkungan alam. Bentuk akuntabilitas semacam ini berfungsi sebagai tali pengikat agar akuntansi syari'ah selalu terhubung dengan nilai-nilai yang dapat "membangkitkan kesadaran keTuhanan". Shariah enterprise theory yang dibangun berdasarkan metafora amanah dan metafora zakat, lebih menghendaki kesimbangan antara sifat egoistik dan altruistik dibanding dengan entity theory. Sementara entity theory lebih mengedepankan sifat egoistiknya daripada sifat altruistik (kepuasan bukan dalam bentuk materi, tapi secara spiritual).

Dengan menggunakan "Epistemologi Berpasangan"dan metafora zakat, shariah enterprise theory berusaha menangkap sunnatuLlab dan menggunakannya sebagai nilai untuk membentuk dirinya. Sharia Enterprise Theory yang dikembangkan berdasarkan pada metafora zakat pada dasarnya memiliki karakter keseimbangan. Secara umum, nilai keseimbangan yang dimaksud adalah keseimbangan antara nilai-nilai maskulin dan nilai-nilai feminin. Sharia Enterprise Theory menyeimbangkan nilai egoistik (maskulin) dengan nilai altruistik (feminin), nilai materi (maskulin) dengan nilai spiritual (feminin), individu-jama'ah dan seterusnya.

Seperti yang telah dijelaskan sebelumnya konsekuensi dari nilai keseimbangan ini menyebabkan Sharia Enterprise Theory tidak hanya peduli pada kepentingan individu (dalam hal ini pemegang saham), tetapi juga pihak-pihak lainnya,. Oleh karena itu, Sharia Enterprise Theory memiliki kepedulian yang besar pada stakeholders yang luas. Menurut Sharia Enterprise Theory, stakeholders meliputi tiga bagian:

1. Tuhan

Tuhan merupakan pihak paling tinggi dan menjadi satu-satunya tujuan hidup manusia. Dengan menempatkan Tuhan sebagai stakeholder tertinggi, maka tali penghubung agar akuntansi syari’ah tetap bertujuan pada "membangkitkan kesadaran keTuhanan" para penggunanya tetap terjamin. Konsekuensi menetapkan Tuhan sebagai stakeholder tertinggi adalah digunakannya sunnatuLlah sebagai basis bagi konstruksi akuntansi syari'ah. Intinya adalah bahwa 
dengan sunnatuLlah ini, akuntansi syari'ah hanya dibangun berdasarkan pada tata-aturan atau hukum-hukum Tuhan.

2. Manusia

Stakeholder kedua dari shariah enterprise theory adalah manusia. Di sini dibedakan menjadi dua kelompok, yaitu direct-stakeholders dan indirectstakeholders. Direct-stakeholders adalah pihak-pihak yang secara langsung memberikan kontribusi pada perusahaan, baik dalam bentuk kontribusi keuangan (financial contribution) maupun nonkeuangan (non-financial contribution). Karena mereka telah memberikan kontribusi kepada perusahaan, maka mereka mempunyai hak untuk mendapatkan kesejahteraan dari perusahaan. Sementara, yang dimaksud dengan indirect-stakeholders adalah pihak-pihak yang sama sekali tidak memberikan kontribusi kepada perusahaan (baik secara keuangan maupun non-keuangan), tetapi secara syari'ah mereka adalah pihak yang memiliki hak untuk mendapatkan kesejahteraan dari perusahaan.

3. Alam

Golongan stakeholder terakhir dari shariah enterprise theory adalah alam. Alam adalah pihak yang memberikan kontribusi bagi mati-hidupnya perusahaan sebagaimana pihak Tuhan dan manusia. Perusahaan eksis secara fisik karena didirikan di atas bumi, menggunakan energi yang tersebar di alam, memproduksi dengan menggunakan bahan baku dari alam, memberikan jasa kepada pihak lain dengan menggunakan energi yang tersedia di alam, dan lainlainnya. Namun demikian, alam tidak menghendaki distribusi kesejahteraan dari perusahaan dalam bentuk uang sebagaimana yang diinginkan manusia. Wujud distribusi kesejahteraan berupa kepedulian perusahaan terhadap kelestarian alam, pencegahan pencemaran, dan lain-lainnya.

Shariah enterprise theory tidak mendudukkan manusia sebagai pusat dari segala sesuatu sebagaimana dipahami oleh antroposentrisme. Tapi sebaliknya, shariah enterprise theory menempatkan Tuhan sebagai pusat dari segala sesuatu. Tuhan menjadi pusat tempat kembalinya manusia dan alam semesta. Oleh karena itu, manusia di sini hanya sebagai

Wakil-Nya (khalituLlah fil ardh) yang memiliki konsekuensi patuh terhadap semua hukum-hukum Tuhan. Kepatuhan manusia (dan alam) semata-mata dalam rangka kembali kepada Tuhan dengan jiwa yang tenang. Proses kembali ke Tuhan memerlukan proses penyatuan diri dengan sesama manusia dan alam sekaligus dengan hukum-hukum yang melekat di dalamnya. Tentu saja konsep ini sangat berbeda dengan entity 
theory yang menempatkan manusia dalam hal ini stockholder sebagai pusat. Dalam konteks ini kesejahteraan hanya semata-mata dikonsentrasikan pada stockholders.

Konsekuensi dari diterimanya shariah enterprise theory sebagai dasar dari pengembangan teori akuntansi syari'ah adalah pengakuan income dalam bentuk nilai-tambah (value-added), bukan income dalam pengertian laba (profit) sebagaimana yang diadopsi entity theory. Baydoun \& Willettdalam islamic accounting theory dan islamic corporate reports-nya telah menunjukkan nilai tambah. Namun apa yang disampaikan oleh mereka sebetulnya masih dalam bentuk yang sederhana dan lebih menekankan pada bentuk penyajian dalam Laporan Nilai Tambah (value added statement).

\section{PEMBAHASAN}

Corporate Social Responsibility (CSR) menurut Bank Syariah Mandiri KC Majalengka. Corporate Social Responsibility (CSR) merujuk pada semuahubungan yang terjadi antara perusahaan dengan semua stakeholders,termasuk pelanggan, pegawai, komunitas, pemilik, pemerintah, supplierbahkan kompetitor. CSR merupakan konsep di mana Bank SyariahMandiri (BSM) secara sukarela menyumbangkan sesuatu ke arahmasyarakat yang lebih baik dan lingkungan hidup yang lebih bersih. BankSyariah Mandiri meyakini bahwa perusahaan bisa tumbuh danberkembang dengan melalui cara lain tetap menjalankan praktek bisnisyang etis dan bertanggung jawab. Oleh karena itu, BSM menempatkankegiatan Tanggung Jawab Sosial Perusahaan (Corporate SocialResponsibility) dalam kerangka upaya perusahaan untuk mencapaikeberlanjutan (sustainability) dalam jangka panjang.

Arti dari bisnis yangberkelanjutan (sustainable business) adalah bahwa perusahaan tidakhanya berupaya untuk memaksimalkan kinerja ekonomi untuk parapemegang saham, tetapi juga secara menyeluruh berusaha untukmemberikan kontribusi yang maksimal dalam aspek sosial danlingkungan. Program CSR mulai dilaksanakan BSM sekitar tahun 2001,yaitu setelah dua tahun berdiri dengan motivasi menjaga nama baik BSMdan untuk membantu sesama baik itu dari segi ekonomi, sosial, danlingkungan. Adapun tujuan BSM melaksananakan program CSR yaitu:

1. Mendukung kesejahteraan masyarakat dan meningkatkan kualitas lingkungan;

2. Mendukung implementasi praktik bisnis yang transparan dan bertanggungjawab;

3. Membuat perubahan positif di tengah masyarakat, khususnya di lingkungan di mana BSM beroperasi; 
4. Membangun citra positif BSM dalam benak masyarakat, danmenggalang dukungan masyarakat untuk tujuan bisnis BSM;

5. Meningkatkan nilai brand BSM dengan membangun reputasi yang baik;

6. Meningkatkan kesadaran publik tentang BSM melalui kegiatankegiatan sosial. (Sumber: BSM)

Bank Syariah Mandiri menggunakan pendekatan tripple bottom lines yang meliputi kinerja ekonomi (economic indicators), kinerjalingkungan (environmental indicators), dan kinerja sosial (social indicators). Dengan ini diharapkan keberadaan Bank Syariah Mandiri tidakhanya bermanfaat bagi para pemegang saham (shareholders), tetapi jugakepada pemangku kepentingan (stakeholders) yang lebih luas yaitumasyarakat dan lingkungan. Dengan kata lain, BSM berusaha untukmemaksimalkan laba perusahaan (profit) selaras dengan tujuan untukmemberikan manfaat yang sebesarbesarnya bagi masyarakat (people),dan lingkungan (planet). BSM meyakini bahwa dengan pendekatan yangmenyeluruh ini akan mendukung tercapainya tujuan pembangunan yangberkelanjutan (sustaibable development), yaitu kegiatan pembangunanyang dilakukan untuk memenuhi kebutuhan generasi sekarang tanpamengorbankan kepentingan generasi mendatang.

Dalam pelaksanaan CSR, BSM bekerja sama dengan Lembaga Amil Zakat Nasional Bangun Sejahtera Mitra Umat (LAZNAS BSM). Yang mana lembaga ini dibangun oleh Yayasan Bangun Sejahtera Mitra Umat (BSM Umat) dan dikukuhkan sebagai Lembaga Amil Zakat berdasarkan Keputusan Menteri Agama Republik Indonesia Nomor 406 Tahun 2002. Dalam menjalankan kegiatannya, LAZNAS ini memiliki 3 jenis program unggulan, antara lain:

1. Program Mitra Umat: berfokus pada pemberdayaan umat melalui bantuan modal kerja yang disalurkan kepada pedagang kecil atau usaha kecil-mikro (UKM). Bila usaha sudah berkembang, maka dana tersebut akan digulirkan kembali kepada individu/pihak lain yang membutuhkan. Individu yang sudah berhasil mengembangkan usahanya, wajib menjadi pembayar zakat (Murakki).

2. Program Didik Umat: berfokus kepada penyaluran bantuan biaya pendidikan atau beasiswa kepada anak-anak kaum dhuafa atau yang berhak menerima zakat agar bisa melanjutkan sekolah.

3. Program Simpati Umat: berfokus pada kegiatan yang bersifat charity, di antaranya: bantuan atau dana zakat yang digulirkan secara langsung kepada 8 golongan yang berhak menerima zakat, maupun masyarakat yang tidak memiliki biaya untuk berobat atau korban bencana alam. 


\section{Konsep dan Implementasi Sharia Enterprise Theory di Bank Syariah Mandiri KC Majalengka}

1. Akuntabilitas Vertikal: Allah SWT

Akuntabilitas terhadap Tuhan yang dapat dianggap sebagai upaya bank untuk memenuhi prinsip syariah antara lain dapat dilihat melalui keberadaan opini Dewan Pengawas Syariah (DPS). Meskipun sebenarnya opini ini lebih pada menjelaskan kepatuhan bank terhadap fatwa Dewan Syariah Nasional (DSN). Triyuwono (2006) 15 pernah menjelaskan bahwa akuntabilitas terhadap Allah dapat dilihat dari kepatuhan terhadap opini Dewan Pengawas Syariah. Laporan Dewan Pengawas Syariah dalam hal ini memberikan jaminan bahwa operasional dan produk bank syariah telah sesuai dengan fatwa Dewan Syariah Nasional (DSN), Majelis Ulama Indonesia, dan Opini DPS. Dilihat dari pengertian di atas maka BSM dalam hal ini dapat dikatakan telah memenuhi akuntabilitas terhadap Allah melalui keberadaan opini Dewan Pengawas Syariah (DPS) dalam laporan tahunannya.

2. Akuntabilitas Horizontal: Direct Stakeholders

a. Akuntabilitas Horizontal terhadap Nasabah

Berkaitan dengan akuntanbilitas terhadap nasabah Bank Syariah Mandiri memberikan perhartian yang cukup besar. Karena salah satu dari nilai-nilai dasar yang diterapkan BSM adalah "Customer Focus" artinyaBSM memahami dan memenuhi kebutuhan pelanggan untuk menjadikan Bank Syariah Mandiri sebagai mitra yang terpercaya dan menguntungkan dengan cara proaktif dalam menggali dan mengimplementasikan ide-ide baru untuk memberikan layanan yang lebih baik dan lebih cepat dibandingkan kompetitor.

Dalam hal peningkatan kepercayaan nasabah terhadap kualifikasi anggota DPS BSM mengungkapkan latar belakang pendidikan, pengalaman, tugas, remunerasi dan rangkap jabatan anggota DPS. Hal ini sesuai dengan tema Syariah Enterprise Theory (SET) yang diajukan Meutia (2010)16 bahwa selain mengungkapkan opini DPS, bank syariah harus mengungkapkan hal-hal yang berhubungan dengan pendidikan, pengalaman, tugas, remunerasi, dan rangkap jabatan anggota DPS

Hal ini menunjukkan bahwa presentase pembiayaan dengan skema bagi hasil lebih rendah jika dibandingkan dengan

\footnotetext{
${ }^{15}$ Agus slamet, mengenal Akuntansi Syariah, (wordpress : 2014)

16 Meutia, Hubungan Manajemen Laba dengan Asimetris Informasi (Blogspot : 2014)
} 
pembiayaan lain, artinya BSM tidak menonjolkan pembiayaan bagi hasil yang mengedepankan prinsip kemitraan dan keadilan sebagai ciri khas bank berlabel syariah. Selain itu BSM tidak melakukan kebijakan untuk memperbesar porsi pembiayaan bagi hasil di masa yang akan datang.

Kegiatan tanggung jawab sosial Bank Syariah Mandiri dilaporkan pada bagian tersendiri. Sumber dana CSR Bank Syariah Mandiri terbagi atas dua yaitu qardulhasan (dana kebajikan) dan dana zakat. Dana kebajikan disalurkan berasal dari pendapatan/ transaksi non halal, denda dan dana operasional. Dalam surat edaran internal bank pendapatan non halal menjadi sumber dana sosial bank yang terdiri dari:

Satu: Dana Sosial Ex Penalty, yakni dana yang berasal dari denda keterlambatan (penalty) pembayaran angsuran atau denda lain yang berhubungan dengan transaksi antar pihak bank dengan pihak ketiga.

Dua: Dana Sosial Ex Jasa Giro, yakni dana sosial yang berasal dari giro yang diterima oleh bank dari penempatan pada bank konvensional sebesar.

Tiga: Dana Sosial Lainnya, yakni dana sosial yang berasal dari komisi, fee, atau dalam pendapatan dalam bentuk lainnya dari rekanan bank selain pendapatan yang berhak diterima sebagai ketentuan manajemen. Jenis kegiatan yang telah mendapatkan penyaluran dana kebajikan CSR meliputi:

(a) Sarana Ibadah: Renovasi Masjid Nurul Muttaqien di daerah Panyingkiran, Majalengka.

(b) Bantuan kesehatan: Kegiatan Donor darah per 3 bulan sekali yang bertempat di Bank Syariah Mandiri Kc Majalengka untuk di salurkan ke PMI Majelengka atau masyarakat yang membutuhkan.

(c) Bantuan pendidikan: Bantuan Komputer untuk santri Asromo (Asromo Islamic Boarding School) desa Pasir Ayu kecamatan sindang kabupaten Majalengka sebanyak 10 unit komputer pada tahun 2015 dan bantuan komputer untuk Tk Al-Lukman Tonjong, Majalengka pada tahun 2016 sebanyak 2 unit.

(d) Kegiatan sosial: Bantuan bagi korban longsor di daerah Gunung kuda pada tahun 2015, total bantuan sebesar 50 juta rupiah.

Dana zakat BSM bersumber dari zakat karyawan, nasabah dan umum disalurkan melalui Lembaga Amil Zakat Nasional Bangun Sejahtera Mitra (LAZNAS BSM) yang penyalurannya 
dilakukan melalui program yang berdaya guna dan bermanfaat yakni Mitra Umat.

b. Akuntabilitas Horizontal terhadap Karyawan

Pentingnya karyawan sebagai salah satu stakeholders cukup disadari oleh Bank Syariah Mandiri, hal ini tercermin dari informasi pengungkapan mengenai karyawan pada laporan tahunan. BSM memastikan setiap pegawainya memiliki kompetensi yang memadai dengan tuntutan kerjanya melalui penyelenggaraan berbagai diklat untuk meningkatkan knowledge \& skill serta memperbaiki behavior masingmasing pegawai.

Bank Syariah Mandiri telah mengungkapkan beberapa item berkaitan dengan karyawan seperti yang dijelaskan dalam Syariah Enterprise Theory (SET) yaitu berkaitan dengan banyaknya pelatihan yang telah diikuti dan banyaknya karyawan yang mengikuti pelatihan, sekaligus rata-rata pelatihan yang diikuti per karyawan setiap tahunnya. Selain itu yang banyak diungkapkan berkaitan dengan karyawan antara lain kebijakan upah dan remunerasi serta kebijakan mengenai kesetaraan kesempatan. Apa yang melatarbelakangi dilakukannya semua program dan strategi yang berkaitan dengan karyawan dinyatakan dengan sangat jelas di laporan tahunan sebagai upaya untuk mewujudkan tujuan perusahaan:

"Sumber daya manusia merupakan aset terpenting perusahaan karena perannya sebagai subyek pelaksana kebijakan dan kegiatan operasional dalam rangka mewujudkan visi dan misi perusahaan. Untuk meningkatkan profesionalisme dan kinerja usaha secara berkelanjutan, Bank telah mencanangkan program pengembangan kualitas sumber daya manusia professional secara konsisten melalui sistem pengelolaan sumber daya manusia secara terpadu." ${ }^{17}$

Sekali lagi tujuan perusahaan menunjukkan kekuasaannya, sebagaimana tujuan perusahaan yang dinyatakan dalam misi adalah "mewujudkan pertumbuhan dan keuntungan yang berkesinambungan". Hal ini berarti bahwa perhatian terhadap kesejahteraan karyawan tidak lebih daripada sekedar strategi secara khusus bagi karyawan yang mendatangkan manfaat ekonomi bagi perusahaan. Oleh karena itu pengungkapan yang berkaitan dengan karyawan pada umumnya berupa pelatihan

${ }^{17}$ Laporan tabunan (Bank Syariah Mandiri 2011), 189

22 Ahmad Nabil Amir - The Influence Of Abduh's 
dan workshop secara khusus bertujuan membantu percepatan bisnis.

1) Pengembangan Pegawai

Sejalan dengan bisnis yang terus berkembang, BSM perlu memastikan setiap pegawainya memiliki kompetensi yang memadai dengan tuntutan kerjanya. Oleh karena itu, bank memberikan kesempatan belajar bagi pegawainya untuk mendukung mereka melakukan yang terbaik dalam pekerjaannya dan terus mengembangkan karirnya. Selain itu, BSM senantiasa meningkatkan anggaran program pelatihan dan pengembangan untuk memperbaiki kemampuan, kapasitas dan produktivitas pegawainya. Program-program yang dilakukan berupa in-house training, public training maupun e-learning.

Selain itu, diklat juga diselenggarakan untuk mengembangkan karir setiap pegawai. Sebagai bentuk apresiasi perusahaan terhadap pegawai yang berprestasi di bidang kerjanya masing-masing, BSM memberikan kenaikan grade dan promosi jabatan. Pegawai yang dipromosikan, baik grade maupun jabatan, terlebih dahulu mengikuti rangkaian seleksi administratif dan uji kompetensi. Kompetensi teknis (hard) diuji melalui media e-learning dan kompetensi perilaku (soft) diuji melalui competency assesment.

Ada tiga jenis program promosi jabatan yang dilakukan oleh BSM yaitu Officer Development Program (ODP), Middle Manager DevelopmentProgram (MMDP), dan Manager Development Program (MDP). OfficerDevelopment Program (ODP) merupakan program yang dikhususkan bagi pegawai yang dipromosikan dengan perubahan level jabatan. Yaitu pegawai dari level jabatan Pelaksana yang dipromosikan ke level jabatan Officer. Sedangkan untuk mempersiapkan pemimpin masa depan Bank telah dilaksanakan Manager DevelopmentProgram (MDP). Menyadari semakin besarnya kebutuhan pegawai akan peningkatan kompetensi maka Bank terus mengembangkan desain diklat.

2) Kebijakan Upah dan Remunerasi

Bank Syariah Mandiri senantiasa berupaya meningkatkan kesejahteraan pegawai berdasarkan pencapaian kinerja melalui penerapan pola guaranted cash dan fasilitas kepegawaian lainnya. Selain apresiasi berupa rewards terhadap kinerja pegawai, BSM juga menerapkan sistem punishment yang adil bagi pegawai yang melakukan penyimpangan atau pelanggaran terhadap ketentuan BSM. Pembinaan yang diberikan berupa teguran, peringatan 
dan sanksi yang disesuaikan dengan tingkat pelanggaran yang dilakukan. Bank berupaya untuk menciptakan paket remunerasi yang atraktif dan kompetitif. Paket remunerasi terus ditinjau ulang untuk memastikan bahwa pegawai Bank mendapatkan paket yang kompetitif. Reward yang diberikan BSM terkait dengan kinerja, antara lain dengan program tunjangan prestasi unit kerja, bonus tahunan, insentif terkait prestasi, dan pemberian beasiswa S2.

3) Perlakuan Adil dan Kesetaraan Kerja

BSM memiliki motto "lebih adil dan menentramkan". Motto tersebut bermakna untuk lingkungan internal (pegawai) dan eksternal (nasabah). Perlakuan adil tercermin dalam pemberian kompensasi kepada pegawai yaitu sesuai dengan prinsip 3P:

a) Pay for Performance: Pegawai diberikan kompensasi sesuai dengan kinerjanya.

b) Pay for Position: Pegawai diberikan kompensasi sesuai dengan posisi/ jabatannya

c) Pay for Person: Pegawai diberikan kompensasi sesuai dengan keahlian individunya.

Di sisi pengembangan kualitas spiritual bagi pegawai, perusahaan berupaya untuk mengembangkan nilai-nilai yang disepakati bersama oleh seluruh pegawai BSM dapat dipandang sebagai bagian dari tanggung jawab sosial perusahaan terhadap kualitas spiritual pegawai. Nilai-nilai tersebut disingkat ETHICS (Excelence, Teamwork, Humanity, Integrity dan Customer Focus), kata "ETHICS" berarti "set of moral principles" yaitu himpunan prinsip-prinsip moral sebagai tatanan perilaku mulia yang membentuk keunggulan insan BSM. Nilai-nilai ini menjadi ruh dalam setiap aktivitas seluruh jajaran pegawai dan pengurus di BSM.

\section{c. Akuntabilitas Horizontal: Indirect Stakeholders}

Perhatian Bank Syariah Mandiri terhadap isu tanggung jawab sosialsecara khusus pada segmen komunitas dapat diamati melalui laporantahunan dengan adanya pengungkapan atas pemberdayaan usaha mikrodan kecil. Pengungkapan atas jenis pembiayaan, skim pembiayaan, danjumlah dana yang disalurkan serta jumlah unit usaha yang menerimapembiayaan setidaknya menunjukkan bahwa BSM mempunyai perhatianlebih atas usaha mikro dan kecil. Perhatian atas 
segmen mikro kecil inidapat dilihat dalam pengungkapan informasi berikut:

"Sebagai bank syariah yang memiliki misi keberpihakan kepadasegmen ekonomi mikro dan kecil, Bank Syariah Mandiri (BSM) terus-menerus berupaya untuk meningkatkan peranannya dalampemberdayaan usaha mikro dan kecil melalui berbagai pembiayaan program." Informasi ini menunjukkan bahwa BSM senantiasa menjaga komitmennyauntuk mendukung pengembangan sektor industri kecil dan menengah.

Hal ini sesuain dengan kerangka yang dianjurkan dalam penelitian Maali (2006) $)^{18}$, bahwabank syariah perlu mengungkapkan pembiayaan untuk mendorong perkembangan ekonomi mikro sebagai bagian dari tanggung jawab sosial perusahaan. Senada dengan Syariah Enterprise Theory (SET) yang menggolongkan informasi mengenai pembiayaan yang diberikan pada sektor UMKM ke dalam sifat daruriyyat (sangat penting) dibandingkan dengan informasi yang mengenai pembiayaan yang diberikan kepada korporat dan komersial. Hal ini dikarenakan melindungi kepentingan orang banyak (usaha kecil yang biasa termarginalkan) lebih penting dalam pandangan syariah dibandingkan kepentingan korporat.

Kepedulian BSM terhadap penigkatan kualitas hidup masyarakat dibidang agama, pendidikan dan kesehatan dapat dilihat dari program dana zakat yang disalurkan, yaitu Mitra Umat, Didik Umat, dan Simpati Umat. Melalui program mitra umat Bank Syariah Mandiri memberikan bantuan yang bertujuan untuk menciptakan kemandirian masyarakat dalam mencapai peningkatan kesejahteraan dalam jangka panjang. Program CSR bidang ini diwujudkan dalam pemberian bantuan permodalan, sarana kerja. Adapun program didik umat yang difokuskan pada peningkatan kualitas pendidikan, yang diwujudkan dalam bentuk pemberian beasiswa kepada siswa dari keluarga kurang mampu. Kegiatan dilaksanakan secara menyeluruh baik di lingkungan Kantor Pusat Bank di Jakarta maupun kantor cabang diseluruh pelosok negeri. Melalui program simpati umat diwujudkan melalui program perbaikan kesehatan dan program sosial.

Program CSR untuk bidang kesehatan difokuskan pada peningkatan kualitas kesehatan masyarakat sekitar yang

18 Ahmad Syarifudin, Konferensi Internasional pembangunan Islami (Academia.edu: 2014) 
diwujudkan dalam bentuk bantuan kesehatan dan pelaksanaan donor darah. Sedangkan program CSR untuk bidang sosial diwujudkan dalam bentuk santunan dhuafa, santunan Ramadhan, bantuan korban bencana alam, bantuan pembangunan dan renovasi masjid dan madarasah. Selain itu Bank Syariah Mandiri juga menjalankan program-program organisasi kemasyarakatan dengan tujuan untuk mensejahterahkan masyarakat.

d. Akuntabilitas Horizontal Alam

Kepedulian Bank Syariah Mandiri terhadap lingkungan dapat dilihat dalam pengungkapan CSR sebagai berikut:

"Program-progam Corporate Social Responsibility (CSR) sebagai bentuk kepedulian Bank terhadap masyarakat dan lingkungan sekitar terus menerus dilakukan dan dikembangkan BSM guna kesejahteraan bersama. Penguatan CSR secara berkesinambungan dan berkelanjutan diharapkan dapat memberikan dampak positif bagi bank. Kedepannya, bank akan membentuk bagian tersendiri guna mengoptimalkan peranan CSR menuju BSM "Clean dan Go Green" mendukung negeri tercinta ini untuk mewujudkan "Green Banking" dalam wujud nyata. $^{19}$

Perhatian Bank Syariah Mandiri terhadap isu lingkungan antara lain ditunjukkan dalam bentuk menyalurkan pembiayaan dan bekerja sama dengan Kementerian Lingkungan Hidup, dengan tujuan untuk mendukung dan ikut serta dalam pelestarian lingkungan hidup. Penyaluran pembiayaan ini pada umumnya dengan memberikan investasi untuk perusahaan kecil dengan memanfaatkan Debt for Nature Swap (DNS) di sektor lingkungan. Selain itu dalam penyaluran dana CSR yang dilakukan BSM, bank juga tidak mengungkapkan penyaluran dana berdasarkan daerah-daerah kantor cabang BSM. Hal ini memungkinkan penyaluran dana CSR tidak merata dan hanya dipusatkan pada daerah tertentu saja. Ini mengindikasikan adanya ketidakadilan BSM dalam penyaluran dana CSR.

Memberikan perhatian pada lingkungan bukan prioritas bagi bank syariah, sekalipun mungkin pelaku bank syariah mengakui bahwa isu kerusakan lingkungan adalah isu yang sangat penting. Begitu pula menurut Syariah Enterprise Theory (SET), alam merupakan salah satu stakeholders yang harus

${ }^{19}$ Laporan Tabunan (Bank Syariah Mandiri : 2011), 163 
mendapat perhatian dan memiliki hak untuk mendapatkan kesejahteraan. Namun demikian perhatian BSM terhadap alam tidak banyak diungkapkan dalam laporan tahunan. Upaya untuk melestarikan atau ikut serta memperbaiki kondisi alam agar menjadi tempat yang lebih baik bagi keturunan mendatang tidak ditemukan dalam pengungkapan yang dilakukan oleh BSM.

\section{Kesesuaian CSR di Bank Syariah Mandiri sudah sesuai dengan Perspektif Sharia Enterprise Theory.}

Keseimbangan merupakan salah satu dari karakteristik Sharia Enterprise Theory (SET) yang menghendaki adanya perhatian terhadap hal yang bersifat material dan spiritual. Dari pengungkapan yang dilakukan oleh Bank Syariah Mandiri walaupun terdapat perhatian terhadap hal-hal yang bersifat spiritual, namun perhatian ini masih sedikit sehingga informasi yang diungkapkan masih belum dapat dikatakan memenuhi karakteristik keseimbangan. Namun demikian pengungkapan tanggung jawab sosial yang dilakukan oleh bank syariah hampir selalu dikaitkan dengan pencapaian hal-hal yang bersifat material (profit).

Terkait dengan keseimbangan dalam bentuk informasi kualitatif dan kuantitatif dalam hal ini Bank Syariah Mandiri telah berusaha memberikan tidak hanya informasi kualitatif melainkan juga data-data kuantitatif.Meskipun demikian data-data yang diungkapkan dalam laporan tahunanini masih perlu dilengkapi untuk dapat menjadi suatu informasipertanggungjawaban sosial yang dapat dipertanggung jawabkan dansesuai dengan konsep Sharia Enterprise Theory (SET). Dari konsep dan implementasi yang telah dijelaskan diatas Corporate Social Responsibility (CSR) yang ada di Bank Syariah Mandiri sudah sesuai dengan Perspektif Sharia Enterprise Theory karena Sharia Enterprise Theory mengandung nilai keadilan, kebenaran, kejujuran, amanah, dan pertanggungjawaban. Nilainilai tersebut telah sesuai dengan karakteristik dari Akuntansi Syariah.

\section{Kesimpulan}

Dari hasil Penelitian tentang Analisis Penerapan Corporate Social Responsibility dalam Perspektif Sharia Enterprise Theory (Studi Kasus Pada Bank Syariah Mandiri KC Majalengka) kesimpulannya sebagai berikut:

Dalam pelaksanaan Corporate Social Responsibility di Bank Syariah Mandiri bekerja sama dengan Lembaga Amil Zakat Nasional Bangun Sejahtera Mitra Umat (LAZNAS BSM). Yang mana lembaga ini dibangun oleh Yayasan Bangun Sejahtera Mitra Umat (BSM Umat) dan dikukuhkan sebagai Lembaga Amil Zakat Dalam menjalankan kegiatannya, LAZNAS ini memiliki 3 jenis program unggulan, antara lain ;Program Mitra Umat, program Didik Umat dan Program Simpati Umat. 
Konsep dan Implementasi Shariah Enterprise Theory di Bank Syariah Mandiri Kc Majalengka meliputi; Akuntabilitas Vertikal (Allah SWT), Akuntabilitas Horizontal :Direct Stakeholders (Akuntabilitas Horizontal terhadap Nasabah, Akuntabilitas Horizontal terhadap Karyawan, Akuntabilitas Horizontal: Indirect Stakeholders) dan Akuntabilitas Horizontal (Alam).

Secara garis besar Corporate Social Responsibility yang dilakukan di Bank Syariah Mandiri Kc Majalengka sudah sesuai dengan konsep Shariah Enterprise Theory karena Shariah Enterprise Theory mengandung nilai keadilan, kebenaran, kejujuran, amanah, dan pertanggung jawaban. Nilainilai tersebut telah sesuai dengan karakteristik dari Akuntansi Syariah. 


\section{DAFTAR PUSTAKA}

\section{Buku:}

Antonio Muhammad syafi'i. Bank Syariah dari teori kepraktik. (Jakarta: Gema Insani, Tazkia Cendekia, 2015)

, Dasar- Dasar Manajemen Bank Syariah. ( Jakarta: Pustaka Alfabeta,2006)

Bungin Burhan, Penelitian Kualitatif, (Jakarta: Kencana Media Grup, 2007)

Emzir, Metodelogi Penelitian Kualitatif Analisis Data, Jakarta: PT,Raja Grafindo Persada,2012)

Iqbal hasan, Misbahuddin, Analisis data Penelitian dengan Statistik, Jakarta; PT, Bumu Aksara, 2004)

Ismail, Perbankan Syariah, (Jakarta: Kencana Prenada Media Grup, 2011)

Karim. Adiwarman A, Bank Islam. (Jakarta : PT. Rajagrafindo Persada, 2011)

Mardikanto Totok, CSR Tanggung Jawab Korporasi (Bandung : Alfabeta ), 2016

Muhammad. Manajemen Bank Syariah. (Yogyakarta : Penerbit Unit penerbit dan percetakan Sekolah Tinggi Ilmu Manajemen YKPN, 2011)

Moleong, Lexy J, Metodologi Penelitian Kualitatif, (Bandung: PT, Remaja Rosdakarya, 2004)

Noor Juliansyah, Metodologi Penelitian: Skripsi, Tesis, Disertasi, Dan Karya Ilmia, (Jakarta: Kencana Prenada Media Grup, 2011)

Saifuddin Anwar, Metode Penelitian, (Yogyakarta: Pustaka Pelajar, 2001)

Sugiyono, Metodologi Penelitian Bisnis, (Bandung: Pustaka Alfabeta, 2008) , Metode Penelitian Kuantitatif Kualitatif dan R\&D, (Bandung: Alfabeta, 2009)

\section{Skipsi dan Jurnal:}

Hafida Andri Safitri "Implikasi Shariah Enterprise Theory melalui value Added Statement untuk menilai tanggung jawab perbankan syariah kepada stakeholder Kurniawati,Pengaruh Ukuran Dewan Komisaris Dan Tipe Industri terhadap pengungkapan CS ( Unswagati : 2016)

Lageranna Akmal, Pelaksanaan tanggung jawab sosial perusahaan (CSR) pada Industri rokok; studi pada Pt djarum kudus, jawa tengah, Universitas hasanudin makassar, 2013

Mansyur Syuhada, Pelaporan Corporate Social Responsibility perbankan syariah

dalam prespektif syariah enterprise theory (studi kasus pada laporan tahunan PT Bank Syariah Mandiri), 2012. 
Rokhlinasari Sri, Teori -Teori dalam Pengungkapan Informasi Corporate Social Responbility Perbankan, Jurnal Al-Amwal (IAIN Syekh Nurjati Cirebon) Suparman, Coorporate Social Responsibility : bentuk tanggung jawab sosial dan kepedulian perusahaan dengan masyarakat, 2013

Suhirman Rivandiyanto, Pengaruh CSR Struktur modal dan grup Corporate governance terhapad kinerja keuangan (Unswagati, 2016)

Venusita Lintang, Pelaksanaan Coorporate Social Responsibility yang terdapat pada dalam prespektif Shariah Enterprise Theory Studi kasus pada Bank Bri syariah dan Bank Mandiri Syariah, 2013.

\section{Internet:}

Diakses dari https://www.syariahmandiri.co.id/category/infoperusahaan/profil- perusahaan/sejarah/ pada tanggal 15 mei 2017 pukul 20.00 WIB.

Diakses dari https://www.syariahmandiri.co.id/category/csr/ pada tanggal 15 mei 2017 pukul 20.00 WIB.

Diakses dari http://mutiara09bahasa,blogspot,co,id/2012/02/definisipendekatan-metode-dan-teknik,html. pada tanggal 15 Februari 2017 pukul : 19:58 WIB.

Emzir, Meto Diakses pada tanggal 15 Februari 2017 dialamat http://tepenr06,wordpress.com/2011/10/30/teknikpengumpulan-data.html. 